удК 72.01

ББК 85.101

\title{
Е.С. КУЗНЕЦОВА
}

\section{СПЕКТР ЦЕННОСТЕЙ ПАМЯТНИКА АРХИТЕКТУРЫ}

Рассмотрены основные ценности, характеризующие памятник архитектуры, в том числе - историческая, художественная, сакральная, научная, градостроительная и утилитарная (функциональная) ценности. Дифференцированы их источники и признаки. Подробно рассмотрены основные ценности, характеризующие памятник архитектуры дифференцированы их источники и признаки. Всего анализируется шесть ценностей: утилитарная, сакральная, историко-мемориальная, художественно-эстетическая, научная, градостроительная. Отдельно рассмотрена способность архитектурных сооружений оказывать эмоциональное воздействие на человека.

Ключевые слова: памятник архитектуры, утилитарная ценность, историческая ценность, сакральная ценность, художественная ценность, научная ценность, градостроительная ценность, эмоциональное воздействие.

$\mathrm{B}$ опросы ценности памятников архитектуры начали занимать исследователей практически одновременно с появлением реставрационной теории. Их разработкой занимались как зарубежные исследователи (А. Ригль, Ч. Бранди, В. Фродль), так и отечественные (Е.В. Михайловский, Д.С. Лихачев, А.В. Иконников, 0.И. Пруцын, Е.Н. Селезнева, А.С. Щенков и др.). Ценности исторических зданий рассматриваются в ряде основополагающих документов: в Венецианской хартии 1964 года, системе критериев ЮНЕСК0, а также в Федеральном законе об объектах культурного наследия (памятниках истории и культуры) народов Российской Федерации и многих других.

\section{НАСЈЕДИЕ}


Основными ценностями исторических зданий специалисты признают историческую (мемориальную) и художественную (эстетическую), а также сакральную, научную, градостроительную и утилитарную (функциональную). Однако в настоящее время известно лишь некоторые системные исследования, посвященные разработке ценностного подхода к архитектурному наследию ${ }^{1}$, но и они не дают четкого понимания того, в чем заключается ценность исторических зданий и из чего она складывается.

\section{Утилитарно-функциональная ценность исторического здания}

Утилитарный аспект произведения искусства заключается в возможности его использования в целях удовлетворения практических потребностей жизни [1]. Исходя из этого, можно утверждать, что утилитарная ценность изначально присуща любому сооружению, поскольку здания всегда возводятся для выполнения определенной функции. По словам Ж.М. Вержбицкого, «специфика произведений архитектуры состоит в том, что материальное (функционально-техническое) и духовное нераздельно слито в них, составляя целостность, которая обладает качествами, не свойственными каждой части в отдельности» [2, с. 23]. Согласно известному высказыванию Петера Беренса, «архитектура служит двум идеалам: практицизму и красоте». В то же время, «утрачивая первичное функциональное назначение, произведение архитектуры не теряет ценностного значения как символа культуры и традиции» [2, с. 23], то есть отсутствие данной ценности у памятника архитектуры не лишает его этого статуса (например, руины, акведуки или триумфальные арки). Тем не менее, утилитарная ценность крайне важна как условие включения архитектурного сооружения в повседневную жизнь человека.

Утилитарная ценность связана с материей здания, как субстанцией, конструирующей определенную форму. Ценность заключена в решениях по организации внутреннего пространства и в некоторых характеристиках самой материи (например, прочность, энергосберегающая или звукопоглощающая способность и прочие), а выражается ценность в таких понятиях как комфорт, безопасность, просторность, возможность исполнять функцию, а также возможность приносить прибыль.

Основные уровни утилитарной ценности:

- способность исполнять функцию (возможность использования в целях удовлетворения потребностей) - базовый уровень утилитарной ценности, который обеспечивается, прежде всего, прочностью

\footnotetext{
${ }^{1}$ 0дной из первых система оценки архитектурной ценности зданий в контексте городской среды была разработана в Дании в 1990 году (InterSAVE). Исследовательская программа ценности наследия осуществлялась также в Лос-Анджелесе, в Институте сохранения памятников фонда им. Гетти в 1998-2005 гг.; результатом программы стал ряд публикаций, представляющих интерес по отдельности, но не выстраивающихся в какую-либо систему.
}

здания, то есть его способностью выдерживать нагрузки без разрушения. Конструктивные элементы не должны обладать критичным процентом износа. Прочное здание безопасно и обеспечивает минимально необходимые условия для использования. Низкий показатель этой характеристики выражается словами «ветхий», «аварийный». Помимо прочности, способность исполнять функцию предполагает определенную целостность здания - крепкие стены без крыши или отсутствие лестниц делают его непригодным для использования;

- комфортность - определяется совокупностью положительных психологических и физиологических ощущений человека в то время, когда он находится в здании. Комфортные условия создаются за счет благоустроенности помещений, просторности, температуры, освещения и вентиляции;

- «гуманность» - термин взят у финского архитектора Алвар Ааалто, но о гуманности говорил и Марк Витрувий, описывая ее как категорию пользы, которая определяется «безошибочным и беспрепятственным для использования расположением помещений и подходящим и удобным распределением их по сторонам света в зависимости от назначения каждого» [3, с. 24]. Гуманная архитектура - значит удобная для существования в ней человека, органически соответствующая его потребностям. Такая архитектура добавляет сил, а не отнимает энергию, она обеспечивает человеку гармоничные условия жизни. Приспособление исторических зданий для удобного использования инвалидами значит превращение их в «гуманные». Историческое здание, приспособленное под библиотеку, в которой можно работать без ущерба для здоровья целый день - гуманное. Больничные стены, которые не угнетают пациентов, а способствуют выздоровлению, свидетельствуют о наличии у здания утилитарной ценности высшего порядка.

\section{Сакральная ценность исторического здания}

Сакральное - святое, священное, то, что противостоит мирскому. Это важнейшая мировоззренческая категория, выделяющая области бытия и состояния сущего, воспринимаемые сознанием как принципиально отличные от обыденной реальности и исключительно ценные.

Архитектурное сооружение, обладающее сакральной ценностью (как правило, это религиозные сооружения), воплощает в себе идеи и образы божественного, священного, активно воздействует на зрителя и дает ему возможность пережить опыт взаимодействия со священным. Достигается это через особую иконографию и организацию внутреннего пространства строения, а также через его связь с местом, наличие священных реликвий или соотнесенность с важными событиями историко-религиозного характера. Архитектура становится сакральной в том случае, если для определенного круга лиц она обнаруживает инобытие. 
Источники (носителей) сакральной ченности в архитектурном сооружении:

- иконография. Сакральная архитектура, как правило, обладает легко опознаваемой иконографией, смысл которой, впрочем, для многих остается сокрытым, но все равно пробуждает религиозные чувства или иные переживания. Мы легко можем понять, что перед нами церковь, часовня, звонница или захоронение благодаря присущим им специфическим архитектурным формам и элементам: куполам, закомарам, апсидам, крестам и пр. Внутреннее пространство подобных сооружений (крестово-купольное устройство, закрытая алтарная часть, «небеса», хоры, живописная система и пр.) также ориентирует зрителя и воздействует на него особым способом. Внешний и внутренний облик сакральных сооружений подчинен строгой системе канонических форм, призванных создать образ Царствия Небесного и вознести душу верующего к высшим материям. По мнению С.С. Ванеяна, «архитектура в лице архитектурной постройки способна соотноситься с некоторым набором истин, вызывать в сознании те или иные смысловые ассоциации или просто стимулировать мыслительные процессы» [4, c. 53]. Таким образом, сооружение, формы которого прочно ассоциируются с присутствием инобытия, мы считаем обладающим сакральной ценностью;

- связь с определенным местом. Нередко место, на котором располагается религиозное сооружение, обладает большим значением и сообщает зданию дополнительную сакральную ценность. 0 важности места мы узнаем через связанное с ним предание, легенду или из истории сооружения. Как отмечал А.С. Щенков, «первым из качеств памятника должна быть названа его связь С конкретным местом. Так, воссоздание в XIX веке Десятинной церкви на месте обнаруженных фундаментов древнего киевского храма делало в глазах современников новую постройку законной преемницей прежней. Связь с местом - исходный пункт всех опытов восстановления памятников, оцениваемых как религиозная или национальная святыня. Сюда же следует отнести такое качество, как сохранность части подлинного материала, включение которого даже в практически новую постройку как бы освящает ее. При этом подлинный материал может полностью скрываться облицовкой: в первой половине XIX века важным считался не столько создаваемый материалом внешний вид, сколько сам факт его присутствия» [5, с. 89]. Г.И. Ревзин отмечает, что «конкретная специфика территории, мифология места, на котором возникает святилище, оказывается своего рода иконографической программой храма, основой его семантики» [6, с. 29]; .

- связь с событием, личностью. Сакральную ценность архитектурного сооружения увеличивает его связь с определенным событием - проявлением священного или взаимодействия с ним. Событие не обязательно должно быть историческим или научно подтвержденным. Это может быть поверье: например о том, что церковь построена на месте видения Богородицы, или что в данном храме мироточат иконы. Это может быть предание: Троице-Сергиева лавра почитается в том числе как место, связанное с деяниями Сергия Радонежского;

- наличие святыни. Святыня способна переносить свою ценность на все сооружение, в котором она находится, расширять диапазон его сакральной ценности. В то же время нельзя сказать, что музей, в котором хранится значимая икона, превращается в сакральное пространство. Успенский собор в Москве до сих пор почитается как место, в котором хранилась Владимирская икона Божией Матери несмотря на то, что сейчас она передана Государственной Третьяковской галерее. В Спасо-Преображенском монастыре Старой Руссы отмечено место, где прежде находилась чудотворная Старорусская икона Божией Матери, перевезенная в Тихвин и там затерявшаяся. Монастырь ныне превращен в музей, но сохраняет, как нам кажется, сакральную ценность благодаря связи со святыней. Святыни редко перемещали из одного храма в другой, как правило, они хранились там веками, по крайне мере, до прихода советской власти, когда церковные ценности вывозились, продавались, терялись. Сейчас их пытаются вернуть именно в те храмы, в которых они когда-то находились;

- «намоленность». Данное качество субъективно, и его наличие определяется людской молвой, отношением прихожан, личными ощущениями и далеко не всегда находится в прямой зависимости от возраста и времени функционирования храма (то есть от количества вознесенных в нем молитв). Некоторые места - внутри и снаружи архитектурной формы - считаются чудодейственными, обладающими целительной или умиротворяющей, сильно «заряженной» атмосферой, но только для определенного круга людей, которые в данном месте ощущают наиболее сильное проявление священного. Неверующий человек если и почувствует в таком месте трепет, то, скорее всего, из-за осознания его древности, подлинности, гармонии или связи с важным историческим событием. Один из ярчайших примеров «намоленного» места - часовня Ксении Блаженной в Петербурге, построенная рядом с местом упокоения святой. Каждый день к этому небольшому храму приходят сотни людей, чтобы прикоснуться к его стенам - это считается лучшим способом обратиться к почитаемой святой.

\section{Историко-мемориальная ценность памятника архитектуры}

По словам А.С. Щенкова, «термином “историко-мемориальная ценность" можно обозначить те содержащиеся в памятнике исторические сведения, которые не просто воспринимаются разумом, но одновременно переживаются эмоционально.

Так, человек может при контакте с памятником не только осознать, но и ощутить свою связь с минувшими 
событиями отечественной истории. В другом случае через посредство архитектуры может возникнуть чувство общности с великими деятелями прошлого, чья жизнь была связана с тем или другим памятником, в третьем преклонение перед созидательными способностями человека, возводившего сооружения» [7, с. 147-148]. Иными словами, историко-мемориальная ценность памятника заключается в способности указывать на прошлое, прояснять его и сохранять память о нем.

В той или иной степени историко-мемориальной ценностью обладает каждое здание, но чем больше его возраст, значительнее события, с которыми оно связано, тем выше ценность. Для города в равной степени важны как исторические памятники-доминанты (квартиры и мастерские известных людей, дворцы, церкви и пр.), так и средовая застройка (жилые и доходные дома, фабрики, служебные строения и т. д.), поскольку те и другие раскрывают разные стороны минувшей жизни. Памятники архитектуры, обладающие исторической ценностью, являются хранилищем разнообразных сведений о прошлом, поддерживают память и преемственность времен, усложняют смысловое пространство города и обогащают повседневный опыт горожанина, в некоторых случаях способствуют формированию особого духа места.

Историческая ценность важна не только для науки, как источник достоверных сведений, но и для каждого, кто взаимодействует с памятником, поскольку дает возможность перенестись в другую эпоху, смотреть глазами человека прошлого. Переживать и понимать историю можно только имея перед собой «обломки прошлого».

Зачем переживать историю? Людям не просто интересно, как было раньше, история для нас - источник вдохновения, идей, опыта и в конечном итоге - способ познания настоящего (через сравнение). А. Э. Гутнов отмечает, что «ощущение своего времени невозможно вне исторического напластования времен <...> само новое осмысляется, как новое, только в сравнении со старым, а без этого лишается временной конкретности своего существования» [8, с. 204].

Источники историко-мемориальной ценности исторических зданий:

- подлинный материал. Памятники - материальные свидетельства тех или иных событий, и только подлинный материал способен передать достоверную и наиболее полную информацию о них. «Подлинные вещи несут в себе некое историческое послание, и их утрата означает разрыв связи времен» [9, с. 58]. Подлинную материю памятника невозможно восстановить или восполнить, поэтому с ее исчезновением стирается память, перекрывается канал, по которому шла информация о прошлом. У подлинного материала есть еще одно важное качество. «Для архитектурного сооружения, понимаемого как памятник истории, ценно не только то, что передает нам черты его изначального облика, но также (и часто в не меньшей степени) все то, что свидетельствует о его жизни во времени - последующие изменения и даже следы естественного разрушения» [10, с. 204]. Позднейшие наслоения, патина времени, следы разрушений - все эти признаки подлинной материи не только хранят информацию о прошлом, но также вызывают трепет («то самое здание, в котором...») и чувство сопричастности истории;

- древность. В Российской Федерации памятниками архитектуры признают здания, возраст которых достиг хотя бы 40 лет [11, ст. 18, п. 7]. В Санкт-Петербурге действует закон «0 режимах зон охраны...», запрещающий сносить здания, построенные до 1917 года. Чем древнее памятник, тем больше событий он пережил и тем уникальнее информация, которую он может передать;

- связь с событием. Все памятники архитектуры так или иначе связаны с историческими событиями - их строили, ими пользовались люди прошлого, и уже в одном этом заключается ценность: «историческую науку памятник интересует как подтверждающая фактологическая структура, являющаяся свидетелем того или иного события, процесса, явления» [12, с. 2]. В то же время памятник может быть задействован в ходе важных исторических событий (дворцовые перевороты, собрания литературных кружков, принятие государственных решений, проведение съездов и т. д.) либо являться результатом этих событий. Как пишет Н.Н. Воронин, «сооружение зданий в Древней Руси очень часто связывалось с определенным событием в поступательном развитии государства или в истории русского народа, память о котором увековечивалась в данном здании, в его образе. Так, здание становилось мемориальным сооружением, “памятником" в буквальном смысле слова» [13, с. 68]. В таких случаях историко-мемориальная ценность зданий становится существенно выше;

- связь с личностью. Данная характеристика близка по смыслу предыдущей. Чем значительнее личность, с которой связано здание, и чем теснее эта связь тем выше его историко-мемориальная ценность. Такой ценностью обладают не только дома выдающихся писателей, художников, политиков, ученых и пр., но и те здания, в которых они просто останавливались, выступали или часто проводили время;

- способность проецировать историю в настоящее. Эта характеристика воздействует на повседневный опыт человека и связана с тем, как памятники создают атмосферу ушедшей эпохи, высвечивают историю, напоминают о прошлых событиях и достижениях и тем самым благотворно влияют на ныне живущих. Чтобы ощутить эту ценностную характеристику, человеку совсем не обязательно читать специальную литературу, проводить исследование, участвовать в экскурсии, ему достаточно просто жить рядом с историческими зданиями. Наиболее успешно данная характеристика реализуется памятником в случае его включенности в ансамбль или ландшафт - благодаря этому создается целостный образ; 
- символизация эпохи. Некоторые архитектурные памятники не просто связаны с конкретным событием или личностью, а воплощают в себе целый пласт истории. Виктор Гюго называл их «накипью от постоянного бурления человеческих сообществ». Итальянский архитектор и ученый Альдо Росси писал, что это произведения, «отмечающие новые этапы в развитии мировоззрения, - знаки масштабных перемен, которые связаны в первую очередь с периодами революций и решающими событиями в историческом развитии города» [14, с. 230]. Как представляется, к таким памятникам можно отнести комплекс Московского Кремля, собор Покрова что на Рву (Василия Блаженного), Казанский собор в Петербурге, Зимний дворец и др.

Следует отметить, что историческая ценность наиболее подвержена влиянию идеологии и может быть сильно преувеличена или занижена в зависимости от политической и социокультурной обстановки.

\section{Художественно-эстетическая ценность памятника архитектуры}

Художественно-эстетическая ценность памятника архитектуры пробуждает в человеке специфические эмоции и переживания, которые можно определить с одной стороны как любование, восхищение, наслаждение, с другой - как преклонение, благоговение, возвеличивание и проч. Источником подобных ощущений является внешний облик здания (форма), его целостный образ, который складывается из множества характеристик: размера, композиции, пропорциональности и соотнесенности элементов, декора, фактуры материала, цвета, игры света и тени, патины и проч. Признавая тесную взаимосвязь эстетических и художественных качеств памятника, их следует все же различать.

По мнению Л.Н. Столовича, эстетическая ценность всегда имеет два плана. «Первый план, или "слой", представляет собой чувственную реальность - внешнюю форму предмета, его величину, цвет, освещенность, фактуру или звучание. Второй план, “слой' - то, что находится за этой чувственной реальностью, то, что в ней проявляется» $[15$, с. 21]. Первый план - эстетическое, второй - художественное.

Художественное - это замысел архитектора, образ, который он создал. Эстетическое - элементы, посредством которых достигается создание художественного образа. «Архитектурный образ выражает тот или иной комплекс идей путем создания архитектурными средствами определенных общих эмоций: впечатления торжества или величия, грубой силы или тонкой одухотворенности, суровой строгости или светлой мечты и т. п.» [13, с. 51].

Художественный образ уникален и неповторим, средства выразительности общие для всех, но их выбор и сочетание рождает бесконечное множество вариантов произведений, которые не обязательно приводят к созданию архитектурного шедевра. Эстетически оценивается, прежде всего, форма произведения, с художественной точки зрения важен его смысл, послание. Художественное не может существовать без эстетического. Отсутствие последнего выводит объект из сферы искусства, но эстетическое - может без художественного. Например, руинированный памятник утрачивает свою художественную ценность, так как более не воспроизводит изначальный замысел архитектора, но при этом сохраняет эстетическую ценность - его облик может вызывать у зрителя сильное эмоциональное переживание, связанное именно с тем, как он выглядит.

Несмотря на различие художественного и эстетического в структуре памятника, мы соединяем их в одну ценность, поскольку они имеют общее начало - замысел архитектора.

\section{Источники художественно-эстетической} ценности:

- целостность, репрезентативность. Целостность это высокий процент сохранившихся форм, читаемая иконографическая система. Разрушенное здание, утратившее большое количество элементов, воспринимается с трудом, сложно зрительно восстановить его облик. «Эстетическая оценка направлена, прежде всего, на целостность форм предмета, выражающую способ его организации и способ существования в контекстах среды и культуры» [16, с. 78]. С другой стороны, как уже упоминалось, руинированный памятник также может быть источником эстетических переживаний, хотя для этого он должен быть включен в определенный контекст - природный или искусственно созданный, чтобы не вызывать негативное чувство заброшенности, упадка, разрушения;

- выразительность художественного образа. В архитектуре, как и в любом произведении искусства, заключены две вещи: выражаемое и то, что его выражает. Каждое произведение архитектуры должно быть проявлением идеи его создателя, некоторым текстом, написанным особым языком, который «базируется на способности пространственных отношений - тектоники, пропорций, ритма, силуэта, цвета, тона - оказывать определенное эмоциональное воздействие на человека» $[16$, с. 74]. С помощью этого языка можно выразить многообразные душевные состояния, сделать здание или бытовую вещь носителем определенного настроения. Выбор этого языка зависит от среды, культуры и конкретной функция сооружения. Художественный образ архитектурного сооружения возникает благодаря построению определенной иконографической системы. Иконография памятника воспринимается «как отражение тех социальных и ритуально-символических (т. е. мировоззренческих) структур, которым здание служит» [5, с. 89]. Обращение к иконографии в сочетании с разносторонним исследованием социальных и эстетически-художественных аспектов искусства является одним из условий верного понимания художественного произведения. Художественную ценность памятника повышает свое- 
образие и неповторимость архитектурного и конструктивного решения, отсутствие каких-либо аналогов в мировой строительной и художественной практике, уникальность сооружения с точки зрения способа воплощения в нем определенного образа. Ценно также и умение соблюсти канон. Для современности большое значение имеют не только оригинальные, но и типичные, характерные для своего времени сооружения. Эстетическое восприятие во многом обусловлено кругом знаний и представлений человека, его опытом, культурной принадлежностью;

- красота. Признание чего-либо красивым является высшей эстетической оценкой. Мера красоты здания с давних пор определяется гармонией и пропорциональностью частей, привлекательностью цвета и игрой света, уподобленностью природе, соответствием цели и т. п.

- Существуют объективные причины, по которым определенные формы, линии, краски отражаются в нашем сознании как красивые. Однако универсальных формул создания красивых зданий не существует, так же как формул, по которым мы можем рассчитать степень красоты того или иного здания. Как пишет Н.Н. Воронин, «качества здания - его объем, высота, характер внутреннего пространства, его освещение и т. п., не требовали их "чтения", то есть расшифровки; они были доступны сознанию народа, действуя "материально" на душу, непосредственно “поражая" чувство» [13, с. 52].

Восприятие красивого во многом иррационально, инстинктивно. Часто для нас красиво то, что выходит за рамки правил, нарушает их. Дж. Рескин считал, что термином «архитектура» мы имеем право называть только такое искусство, «которое, допуская и используя требования и методы строительства, накладывает на создаваемые ею вещи свойства и качества быть чем-то прекрасным и достойным почитания, хотя и не являющиеся необходимыми» $[17$, с. 56]. Красота является чем-то «безусловно ценным, что существует не ради другого, а ради самого себя, что самим существованием своим радует и удовлетворяет нашу душу, которая на красоте успокаивается и освобождается от жизненных стремлений и трудов» [18, c. 35].

Кажется, что с течением времени представление о красоте меняется, на самом деле происходит выбор тех или иных ее форм, либо заблуждение, подмена красоты другими явлениями как следствие сложившейся моды, культурной ситуации и пр. По словам У. Эко, «красота никогда не была чем-то абсолютным и неизменным, она приобретала разные обличия в зависимости от страны и исторического периода» [20, с. 8].

Важно, чтобы новое понимание красоты не вытесняло и не отрицало старое. Идеи красоты развиваются и возвращаются. Французский архитектор и реставратор Виоле-ле-Дюк называл собор Василия Блаженного «огородом чудовищных овощей» [35, с. 8], его мнение сильно повлияло на отношение русских людей к собственной архитектуре. Сегодня сложно найти человека, который не восхищался бы самобытной красотой этого храма. Очень долго в постройках древнерусских архитекторов не видели никакой красоты и ценности, считали их варварскими, но в XIX веке их красоту открыли, стали любоваться асимметрией, неровностью стен и т. д. Долго ждали признания московская школа, потом архитектура барокко. Сегодня мы открываем красоту построек конструктивизма.

Нельзя утверждать, что каждое здание может быть признано красивым, в зависимости от оценки смотрящего. Если уродливое здание кем-либо признается красивым, значит, в его оценке проявляются субъективные факторы - воспоминания, ассоциации, давление моды, либо смотрящий принимает за красоту нечто другое - особую атмосферу, историческую нагрузку, очарование окружения и пр. Справедливо и обратное: если кто-либо считает красивое здание уродливым, значит, у него не в полной мере развито эстетическое чувство, понимание красоты, недостаточно знаний об архитектуре либо здание кажется непривлекательным из-за плохого окружения.

\section{Научно-познавательная ценность памятника архитектуры}

Научно-познавательная ценность памятника архитектуры определяется объемом сведений, которые может дать его изучение: об уровне производительных сил общества, социальном устройстве, конструктивных особенностях и приемах возведения сооружений, развитии архитектурных форм, художественных взглядах, религиозных воззрениях и т. д. Поскольку памятник «создан в данном месте, в данное время, при определенных местных условиях», он «представляет собой многогранный, комплексный источник, позволяющий судить как о его производственно-технической, так и об идеологической, художественной стороне» [13, с. 43].

Изучение памятника как объекта материального наследия дает сведения иного порядка, нежели полученные из письменных источников. Джон Рескин называл архитектуру всесильным победителем забвения, считая важным, «чтобы с нами оставалось не только то, что люди думали и чувствовали, но и то, что они сделали своими руками, что произвел их труд и на протяжении всей их жизни видели их глаза».

\section{Источники научной ценности в памятнике архитектурного наследия:}

- материал. Изучение материала, из которого построен памятник, а также связующих растворов, может дать самые разнообразные сведения. В 70-е годы прошлого века М.И. Мильчик писал: «Легко предположить, что в будущем даже из незначительных фрагментов станут извлекать информации все больше, нежели это делаем мы, изучая сохранившиеся памятники. <...> Анализ размеров кирпичей в сооружениях домонгольской поры помогает их датировать, а дендро-хронологический метод сделал возможным точно определять 
“возраст" деревянных конструкций» [21, с. 28]. С тех пор стали применяться еще более точные методы датирования материала - радиоуглеродный, массспектрометрия. Благодаря исследованию деревянных конструкций старинных церквей было выявлено, что все свойства древесины с течением времени изменяются, но не прямо пропорционально времени, а циклично. Возможно, со временем подлинный фрагмент будет играть роль ДНК, с помощью которой специалисты смогут реконструировать истинный вид исчезнувшего строения, вычислить все стадии его изменения;

- инженерные решения. «Анализ материально-технических качеств памятников позволяет судить почти непосредственно о производительных силах общества, о его технической вооруженности и знаниях <...> Изучение конструкции памятника, системы его фундаментов, кладки стен, опор и перекрытий вскрывает сумму накопленного зодчими технического опыта и его усовершенствования» [13, с. 44-46];

- формы: типичные / уникальные. Изучение иконографии зданий важно для истории искусства, поскольку позволяет проследить развитие архитектурных форм. Для искусствоведения одинаково значимы как типичные для своего времени постройки, так и новаторские или не укладывающиеся в стилистические рамки здания. Кроме того, изучение иконографии важно для современных архитекторов, так как может стать опорой и источником вдохновения в их собственном творчестве;

- авторство, школа. Установление автора памятника или причисление его к тому или иному художественному направлению (школе) позволяет обогатить знания об архитектуре. Это важно и для самого памятника: в случае утраты каких-то элементов и отсутствия обмеров можно привлечь аналогии.

\section{Градостроительная ценность памятника архитектуры}

Градостроительная ценность памятника архитектуры заключается в его градоформирующем значении и складывается из характеристик расположения, функции, а также влияния на примыкающие городские ансамбли. Совокупность зданий формирует город, который, в свою очередь, являясь сложной динамической системой, формирует контекст бытования здания, задает условия и предъявляет требования к его существованию. Таким образом, важны два качества здания: роль в образовании пространства города и способность отвечать на его запросы.

Градостроительной ценностью обладают не только архитектурные доминанты - признанные шедевры, но и средовая историческая застройка, которая является наиболее приемлемым «фоном» для этих доминант.

Характеристики градостроительной ченности:

- включенность в ткань города. Отдельные здания в совокупности образуют ансамбли и ландшафт всего города. Как отдельное архитектурное сооружение должно быть гармоничным и пропорциональным, так же должен быть устроен и весь город - его улицы, площади, дороги и т. д. Гармонизация общего пространства города достигается за счет соблюдения высотного регламента, общего стиля, отсутствия лакун. Новые строения в идеале должны проектироваться так, чтобы не вступать в диссонансные отношения со старой архитектурой. Старые здания являются опорой, базой, на основе которой происходит дальнейшее развитие города. Данная ценностная характеристика тем выше, чем значительнее элемент города, в создании которого участвует здание (оживленная городская площадь, главная улица или жилой квартал, внутренний двор) и чем значительнее эстетическая роль самого здания в формировании этого элемента;

- вертикальное или визуальное доминирование. «Классический город формируется за счет наличия доминант. Причем домината характеризуется, как правило, степенью визуальной значимости, высоты, а также ролью в силуэте общей панорамы города» [22]. Вертикальные и визуальные доминанты служат ориентирами в пространстве города, задают высотный регламент, подчиняют себе прилегающую застройку. Такими доминантами обычно являются признанные архитектурные шедевры и здания, обладающие выдающимися художественными и историческими характеристиками: городские кремли, кафедральные соборы, дворцы, крепости и пр.;

- выполняемая функция. Городская функция - это комплекс решаемых архитектурой материально-практических и информационных задач. Можно сказать, что функциями определяются связи между архитектурой и обществом. Часто здания выполняют не ту функцию, которая нужна данной части города, либо не первоочередную, либо вообще не используется, и таким образом сооружения не приносят городу возможной пользы. Правильно выбранная функция способна решать масштабные городские проблемы: регулирование транспортных и людских потоков, увеличение коммуникаций между жителями города, развитие депрессивных районов и т. д. В случае успешного функционирования здание может превратиться в горизонтальную доминанту. «В отличие от вертикальной доминанты, горизонтальная оказывает влияние на город не за счет размеров или местоположения, а благодаря привлекательности ее функционального решения» [22]. Например, перепрофилированная в галерею фабрика способна превратить бывший промышленный район в средоточие творческих сил города.

\section{Эмоциональное воздействие памятников архитектуры}

В результате сочетания всех или нескольких из вышеперечисленных ценностей памятник может оказывать определенное эмоциональное воздействие на зрителя. Как представляется, не следует выделять эту способность 
в отдельную ценность, поскольку она носит слишком субъективный характер и всегда зависит от наличия других ценностей.

Эмоциональное воздействие архитектуры на зрителя достаточно сложно выявить и описать. Оно связано, прежде всего, с историческими и эстетическими характеристиками здания, создающими особую атмосферу, дух места, которые способны погрузить человека в прошлое, вдохновить его, настроить на определенный лад.

Эмоциональное воздействие наиболее велико там, где образовано Место. Альдо Росси понимает Место как уникальный факт, который определяется «пространством и временем, его топографическими размерами и формой, его бытием в качестве арены древних и новых событий, его памятью» [14, с. 223]. К. Дэй пишет об этом явлении следующим образом: «Как возникают Места? В прошлом места вырастали из небытия неспешно, когда всякое новое здание, каждая поправка, да и само чувство места, служили ответом изменению потребности <...> проходило время и место, образованное различными под-местами, развивало отчетливо индивидуальные свойства. Различные обстоятельства, политические, экономические, географические, культурные влияли на рисунок и последовательность стадий роста, результатом чего становились очень развитые формы поселений» [23, с. 130]. Таким образом, Место это фрагмент городской среды, обладающий цельностью и яркой индивидуальностью, складывающейся за счет его эстетических и исторических характеристик.

Если в городе есть Места, он становится привлекательным для жителей, интересным для приезжих. «Среда может стать обитаемой, только если она предлагает широкую гамму возможностей для идентификации <...> Человеческая жизнь не может разворачиваться где угодно, ей требуется особое пространство, которое на самом деле всегда представляет собой миниатюрный космос, систему осмысленных мест» [24, с. 190]. Место как часть городского пространства не может быть сформировано без участия исторических зданий.

Любой город со всеми его зданиями и местами постоянно воздействует на человека и в итоге определенным образом формирует его. «Подобно тому, как люди исторически формируются в определенном климате, они также формируются в конкретном месте, впитав в себя его индивидуальность» [14, с. 222].

Если во многих городах и местах сохранилась историческая архитектура, то это еще не значит, что все они обладают своим собственным, легко опознаваемым лицом или духом, который также называют гением места (genius loci). Признавая важность духа места, специалисты создали специальную декларацию², в которой попытались объяснить суть и значение этого феномена. В декларации дух места определяется как материальные и нематериальные, физические и духовные элементы, которые придают территории ее индивидуальный характер, смысл, эмоци-

\footnotetext{
${ }^{2}$ Квебекская декларация о сохранении духа места. ИКОМОС. Принята в Квебеке в 2008 году.
}

ональность и таинственность. Дух создает пространство, и в то же время пространство создает и структурирует этот дух.

Попробуем найти те источники, из которых рождается эмоциональное воздействие памятника архитектуры и дух места:

- художественный образ. Задуманный архитектором или градостроителем художественный образ здания или места может вызывать чувство торжественности (парадная Дворцовая площадь), возвышенности (Никольский собор), величия (Исаакиевский собор), уюта (дворы, маленькие площади) и т. д. Как правило, мы не оцениваем качество архитектурного сооружения, его художественный образ или материалы, из которого оно построено. Мы воспринимаем здания целиком и в совокупности с их окружением, впитываем их без особых рассуждений. При этом чаще всего мы можем определить назначение здания (религиозное, общественное, жилое и пр.), а в иных случаях, если подобное было задумано архитектором или сложилось в результате исторических событий, испытываем определенные эмоции и ощущения;

- внешний облик (патина времени и исторические наслоения). Здание не доходит до нас в том виде, в каком его оставил автор, поэтому к эстетико-эмоциональным ощущениям, вызванным художественным образом, добавляются также впечатления от тех материальных свидетельств, которые время и история оставили на памятнике. Творить атмосферу или дух места способны такие проявления индивидуальности здания как трещины, обсыпанная штукатурка, «тень» снесенного дома на стене оставшегося, покосившееся крыльцо, могучие двери на засове и пр.

- подлинный материал; с точки зрения эмоционального восприятия памятника подлинный материал важен как истинный свидетель событий прошлого: «именно тот дом, в котором жил», «те ступени, по которым шла», «те стены, которые видели» и т. д. Причем фактическое наличие подлинника не обязательно - для эмоционального воздействия важно, чтобы зритель был уверен, что перед ним «те самые» камни. «Воздействие на душу оказывают не подлинные вещи, а подлинные чувства» [9, с. 56];

- связь с историей. Как мы уже сказали, дух места складывается из множества элементов, но прежде всего, он обязан своему появлению истории. Наше воображение будоражит знание того, что здесь была мастерская художника, по этим улицам ходили герои романов любимого писателя, здесь устраивались лучшие в городе балы, а в этом флигельке продавали сбитень. С другой стороны, знание хорошо, но еще лучше, когда сам воображаешь, что могло здесь происходить. Очень важно, чтобы человек мог получать такие исторические ассоциации в повседневной жизни, а не только в музее или на экскурсии;

- ансамблевость, комплексность, окружение. Включенность здания в ансамбль или гармоничное природное 
окружение значительно увеличивает его эмоциональное воздействие. Приведем обратный пример. Сохранившиеся в большом количестве церкви древнего Пскова сами по себе прекрасны и удивительны. Своей древностью, необычными формами, «живой» поверхностью стен, богатой историей они должны производить на зрителя неизгладимое впечатление. Но этого не происходит из-за полного отсутствия исторического или сколько-нибудь подходящего природного окружения.

Таким образом, каждая ценность определяется рядом характеристик и имеет диапазон. Та или иная ценность выражена у разных памятников в большей или меньшей степени, обладает разным качеством и потенциально может быть увеличена.

Ценности памятника условно можно поделить на абсолютные и относительные. Абсолютные ценности это историко-мемориальная, художественно-эстетическая и научная. Наличие этих ценностей обусловливает само существование памятника архитектуры (без них здание памятником не является), причем научная ценность выступает как комплементарная по отношению к исторической и художественной ценности и сама по себе не возникает.

Абсолютные ценности - это данность; они могут быть только раскрыты, но не увеличены. Другие ценности (утилитарная, сакральная, градостроительная, а также способность эмоционального воздействия) также зависят от исторической и художественной ценности. Однако они могут быть увеличены до определенного уровня теми или иными способам, а могут быть даже добавлены.

Выявление всех ценностей памятника архитектуры и осознание их масштаба позволяет понять, что необходимо сохранить, чем можно пожертвовать, а что стоит развивать.

\section{Список литературы}

1. Власов В.Г. Новый энциклопедический словарь изобразительного искусства: В 10 т. - СПб: Азбука-классика, 2004-2009.

2. Вержбицкий Ж.М. Архитектурная культура. Искусство архитектуры как средство гуманизации «второй природы». СПб.: ИД «АРДИС», 2010.

3. Витрувий. Десять книг об архитектуре. - М.: Либрком, 2013.

4. Ванеян С.С. Архитектура и иконография. «Тело символа» в зеркале классической методологии. - М.: Прогресс-традиция, 2010.
5. История и теория реставрации памятников архитектуры / сб. науч. трудов ЦНИИТИА под ред. А.С. Щенкова. - М.: Стройиздат, 1986.

6. Ревзин Г.И. Очерки по философии архитектурной формы. - М.: ОГИ, 2002.

7. Современный облик памятников прошлого: (Ист.-худож. пробл. реставрации памятников архитектуры) / под ред. А.С. Щенкова. - М.: Стройиздат, 1983.

8. Гутнов А.Э. Города и люди: избранные труды. - М.: МП Ладья, 1993.

9. Маковецкий Е.А. Подражание идеологии: парадоксы культурного наследия. // Вопросы культурологии. - 2012. — № 3.

10. Реставрация памятников архитектуры: учеб. пособие для студентов вузов / С.С. Подъяпольский, Г.Б. Бессонов, Л.А. Беляев и др.; под общ. ред. С.С. Подъяпольского. М.: Стройиздат, 2000.

11. Федеральный закон от 25 июня 2002 г. № 73-Ф3 «0б объектах культурного наследия (памятниках истории и культуры) народов Российской Федерации» // Российская газета. [Электронный ресурс]. - Режим доступа: http://www. rg.ru/2002/06/29/pamjatniki-dok.html

12. Лысова Н.Ю. Архитектурное наследие: проблема ценности: дис. ... канд. филос. наук: 24.00.01 / Н.Ю. Лысова. - Саранск, 1997.

13. Воронин Н.Н. Архитектурный памятник как исторический источник: заметки к постановке вопроса / Н.Н. Воронин // Советская археология. Вып. 19. - 1954.

14. Росси А. Архитектура города. Уникальность городских артефактов / Альдо Росси // Проект International. — 2011. — № 28.

15. Столович Л.Н. Эстетическая и художественная ценность: сущность, специфика, соотношение / Л.Н. Столович. - М.: Знание, 1983.

16. Эстетические ценности предметно-пространственной среды. - М.: Стройиздат, 1990.

17. Рескин Дж. Семь светочей архитектуры. - СПб.: Азбукаклассика, 2007.

18. Соловьев В.С. Философия искусства и литературная критика.- М.: Искусство, 1991.

19. Эко У. История красоты. - М.: СЛОBO/SLOVO, 2013.

20. Грабарь И.Э. История русского искусства. - М., 2009.

21. Мильчик. М.И. Подлинник или копия? 0 границах архитектурной реставрации / М.И. Мильчик // Ленинградская панорама. - 1982. - № 8.

22. Волкова Н.А. Динамика городских доминант как основа устойчивого развития города. // Архитектура и современные информационные технологии. - №4 (9). - 2009. [Электронный ресурс]. - Режим доступа: http://www. marhi.ru/AMIT/2009/4kvart09/Volkova/Article.php (Дата обращения 19.05.2013)

23. Дэй К. Места, где обитает душа: Архитектура и среда как лечебное средство. - М.: МП «Ладья», 1994.

24. Норберг-Шульц К. Жизнь имеет место / пер. с англ. В. Иовлев // Architecton. - 1995. - № 1, 2. 